\title{
Re-evaluation of the 1921 Peak Discharge at Skagit River near Concrete, Washington
}

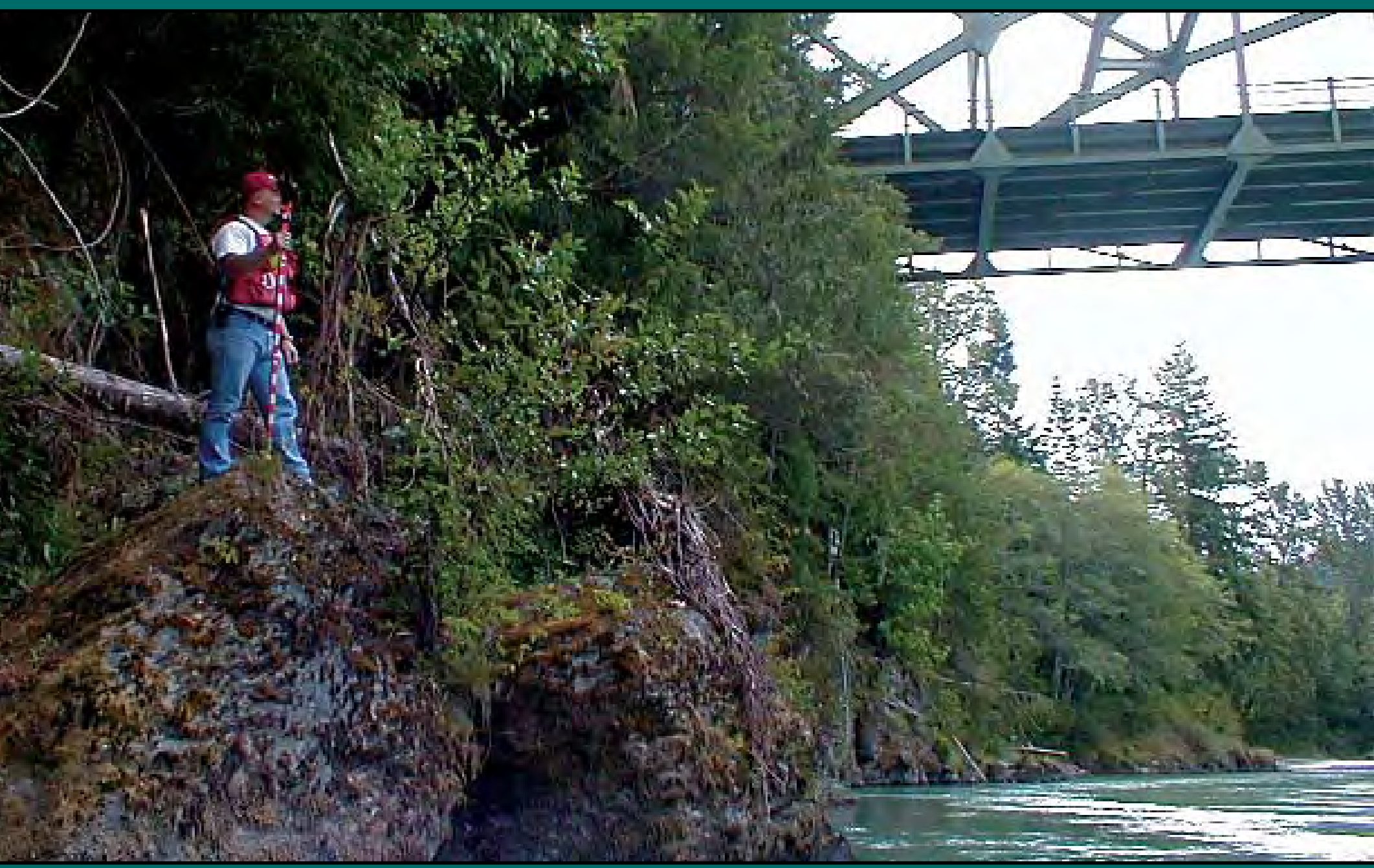

Scientific Investigations Report 2007-5159 
Cover: Photograph of Darrin Miller, U.S. Geological Survey, surveying a high water mark left from the 2003 flood on the right bank of the Skagit River on the mouth of the Dallas Gorge near Concrete, Washington. (Photograph taken by Jeffrey Paulat, U.S. Geological Survey, August 2004). 


\section{Re-evaluation of the 1921 Peak Discharge at Skagit River near Concrete, Washington}

By M.C. Mastin

Scientific Investigations Report 2007-5159 


\title{
U.S. Department of the Interior DIRK KEMPTHORNE, Secretary
}

\author{
U.S. Geological Survey \\ Mark D. Myers, Director
}

\section{U.S. Geological Survey, Reston, Virginia: 2007}

For product and ordering information:

World Wide Web: http://www.usgs.gov/pubprod

Telephone: 1-888-ASK-USGS

For more information on the USGS--the Federal source for science about the Earth, its natural and living resources, natural hazards, and the environment:

World Wide Web: http://www.usgs.gov

Telephone: 1-888-ASK-USGS

Any use of trade, product, or firm names is for descriptive purposes only and does not imply endorsement by the U.S. Government.

Although this report is in the public domain, permission must be secured from the individual copyright owners to reproduce any copyrighted materials contained within this report.

Suggested citation:

Mastin, M.C., 2007, Re-evaluation of the 1921 peak discharge at Skagit River near Concrete, Washington: U.S.

Geological Survey Scientific Investigations Report 2007-5159, 12 p. 


\section{Contents}

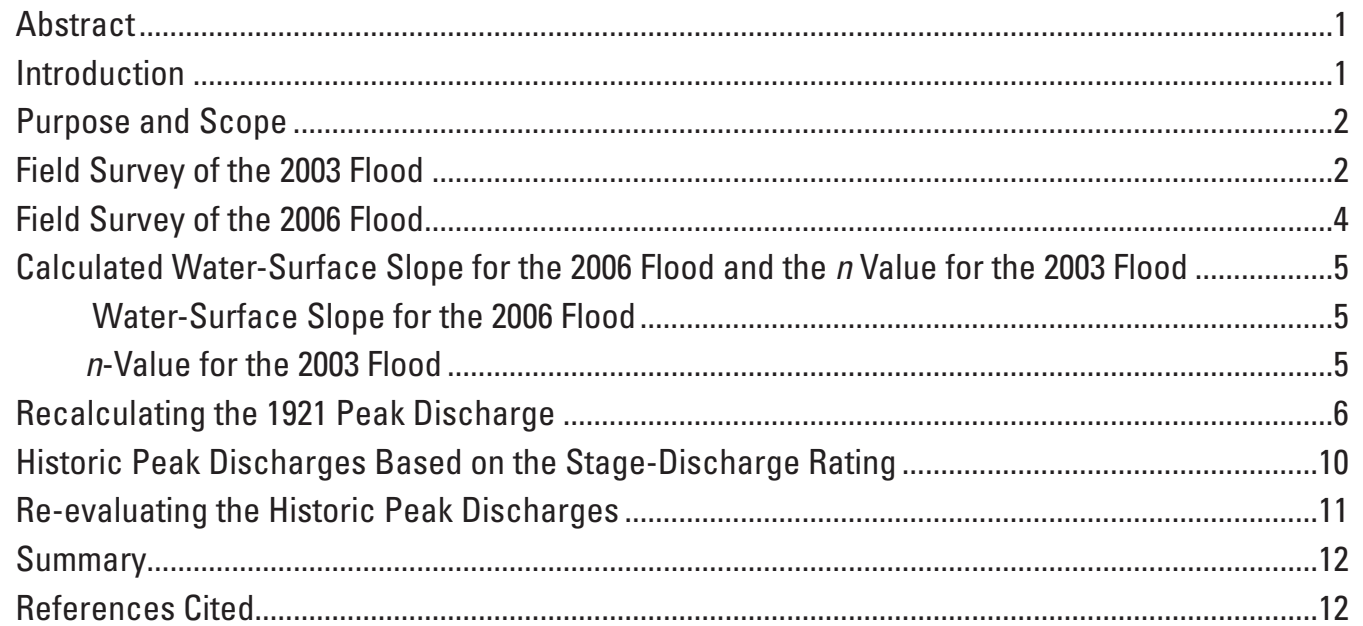

\section{Figures}

Figure 1. Topographic map of the slope-area measurement reach on the Skagit River near Concrete showing the three cross sections (XS1, XS2, and XS3), the streamflow-gaging station, and HWMs from the 2003 flood and the 2006 flood surveyed by the U.S. Geological Survey

Figure 2. Profile showing high-water marks (HWMs) from peak flow of November 6 , 2006, that was surveyed November 21, 2006, by the U.S. Geological Survey on the right bank between cross sections 2 (XS2) and 3 (XS3) on the Skagit River about 3,000-5,000 feet downstream of the streamflow-gaging station, Skagit River near Concrete, Washington (station No. 12194000)

Figure 3. Cross section XS2 as surveyed in 1923 and 2004, $n$ values for the particular subareas $(n)$, peak water surface for the 1921 and 2003 floods, and the points at which the cross sections were subdivided into two subareas

Figure 4. Historical photographs showing only small, sparse brush on the island/bar near cross section 2, Skagit River, Washington.

Figure 5. Profile showing high-water marks (HWMs), cross sections (XS), and water-surface profile from the peak flow of November 27, 1949 on the Skagit River about 3,000-5,000 feet downstream of the streamflow-gaging station, Skagit River near Concrete, Washington (station No. 12194000)

Figure 6. Cross sections $B, C$, and $D$ and the $n$ values $(n)$ used in the $n$-verification study based on the 1949 peak discharge at Skagit River near Concrete, Washington

Figure 7. Stage-discharge rating based on revised 1921 peak discharge recalculation extended to a gage height of 69.3 feet and the current stage-discharge rating for Skagit River near Concrete, Washington, showing selected discharge measurements, published historical peak discharges, and the proposed revised historic peak flows 


\section{Table}

Table 1. Revised peak discharges for Skagit River near Concrete, Washington

\section{Conversion Factors}

\begin{tabular}{lcl}
\hline Multiply & \multicolumn{1}{c}{ By } & To obtain \\
\hline cubic foot per second $\left(\mathrm{ft}^{3} / \mathrm{s}\right)$ & 0.02832 & cubmic meter per second $\left(\mathrm{m}^{3} / \mathrm{s}\right)$ \\
foot $(\mathrm{ft})$ & 0.3048 & meter $(\mathrm{m})$ \\
foot per second (ft/s) & 0.3048 & meter per second $(\mathrm{m} / \mathrm{s})$ \\
inch (in.) & 2.54 & centimeter $(\mathrm{cm})$ \\
inch (in.) & 25.4 & millimeter $(\mathrm{mm})$ \\
\hline
\end{tabular}




\title{
Re-evaluation of the 1921 Peak Discharge at Skagit River near Concrete, Washington
}

\author{
By M.C. Mastin
}

\section{Abstract}

The peak discharge record at the U.S. Geological Survey (USGS) gaging station at Skagit River near Concrete, Washington, is a key record that has come under intense scrutiny by the scientific and lay person communities in the last 4 years. A peak discharge of 240,000 cubic feet per second for the flood on December 13, 1921, was determined in 1923 by USGS hydrologist James Stewart by means of a slope-area measurement. USGS then determined the peak discharges of three other large floods on the Skagit River $(1897,1909$, and 1917) by extending the stage-discharge rating through the 1921 flood measurement. The 1921 estimate of peak discharge was recalculated by Flynn and Benson of the USGS after a channel roughness verification was completed based on the 1949 flood on the Skagit River. The 1949 recalculation indicated that the peak discharge probably was 6.2 percent lower than Stewart's original estimate but the USGS did not officially change the peak discharge from Stewart's estimate because it was not more than a 10-percent change (which is the USGS guideline for revising peak flows) and the estimate already had error bands of 15 percent. All these flood peaks are now being used by the U.S. Army Corps of Engineers to determine the 100-year flood discharge for the Skagit River Flood Study so any method to confirm or improve the 1921 peak discharge estimate is warranted.

During the last 4 years, two floods have occurred on the Skagit River $(2003,2006)$ that has enabled the USGS to collect additional data, do further analysis, and yet again re-evaluate the 1921 peak discharge estimate. Since 1949, an island/bar in the study reach has reforested itself. This has complicated the flow hydraulics and made the most recent recalculation of the 1921 flood based on channel roughness verification that used 2003 and 2006 flood data less reliable. However, this recent recalculation did indicate that the original peak-discharge calculation by Stewart may be high, and it added to a body of evidence that indicates a revision in the 1921 peak discharge estimate is appropriate.
The USGS has determined that a lower peak-discharge estimate (5.0 percent lower) similar to the 1949 estimates is most appropriate based on (1) a recalculation of the 1921 flood using a channel roughness verification from the 1949 flood data, (2) a recalculation of the 1921 flood using a channel roughness verification from 2003 and 2006 flood data, and (3) straight-line extension of the stage-discharge relation at the gage based on current-meter discharge measurements. Given the significance of the 1921 flood peak, revising the estimate is appropriate even though it is less than the 10-percent guideline established by the USGS for revision. Revising the peak is warranted because all work subsequent to 1921 point to the 1921 peak being lower than originally published.

\section{Introduction}

The peak discharge record at the U.S. Geological Survey (USGS) gaging station Skagit River near Concrete, Washington, is a key record being used by the U.S. Army Corps of Engineers to determine the 100-year flood discharge for the Skagit River Flood Study. The four largest annual peak discharges of record that are used to determine the 100-year flood discharge for this station occurred in 1897, 1909,1917 , and 1921. A peak discharge of $240,000 \mathrm{ft}^{3} / \mathrm{s}$ for the flood on December 13, 1921, was determined in 1923 by USGS hydrologist James Stewart by averaging the results of a contracted-opening measurement and slope area. The peak discharges of the other three largest floods were determined from a stage-discharge rating after extending it on the basis of the slope-area peak discharge of the 1921 flood. The accuracy of the peak discharge of the 1921 flood has been questioned, thus putting into question the accuracies of the other three largest peak discharges. The peak discharge of the 1921 flood was first checked in the 1950s with a channel roughness coefficient ( $n$ value) verification study based on the 1949 peak discharge of $153,000 \mathrm{ft}^{3} / \mathrm{s}$ that included a survey of high-water marks (HWMs) and four cross sections in the same reach used by James Stewart for his original slope-area measurement. 
H.C. Riggs and W.H. Robinson (U.S. Geological Survey, written commun., 1950) used this data to calculate an $n$ value for the reach. In 1952, F.J. Flynn and M.A. Benson (U.S. Geological Survey, written commun., 1951-52) revised the $n$-verification study and used the revised $n$ value to recalculate the 1921 peak discharge with channel geometry data compiled by James Stewart. They calculated a peak discharge of $225,000 \mathrm{ft}^{3} / \mathrm{s}$ for the 1921 peak discharge. G.L. Bodhaine (Area engineer, U.S. Geological Survey, written commun., 1954) agreed with the analysis of F.J. Flynn and M.A. Benson, and reasoned that the other historical peak discharges also should be lower than the published values. Based on extension of the stage-discharge rating for the gage that was constrained to pass through the 1921 revised discharge point, he lowered peak-discharge values for all other historical peak discharges except for the 1815 flood, which remained the same. However, he noted that because none of the revisions were more than the 10 percent guideline used to decide if revisions are needed, the published values should not be changed.

The validity of the original slope-area measurement of the 1921 flood was recently re-evaluated by recalculating the peak discharge using an $n$ value based on an $n$-verification analysis done following the flood on October 21, 2003. The peak discharge associated with the 2003 flood was determined to be $166,000 \mathrm{ft}^{3} / \mathrm{s}$ from the current stage-discharge rating (Mastin and Kresch, 2005). However, a considerable amount of variation in the elevation of surveyed HWMs for the flood on October 21, 2003, precluded the determination of a single definitive water-surface slope for use in the $n$-verification analysis. The variability in surveyed HWMs for the flood on October 21, 2003, was attributed to the length of time between the event and the actual field survey, which was not completed until 9 months later in July-August 2004. Consequently, a range of water-surface slopes produced a range of possible $n$ values (Mastin and Kresch, 2005).

A peak discharge of $145,000 \mathrm{ft}^{3} / \mathrm{s}$ on November 6-7, 2006, determined from the current stage-discharge rating provided an opportunity to survey a peak water-surface slope soon after the flood using high-water marks. Access to the left bank of the study reach had to be made by boat, which was unavailable at the time, so only the HWMs on the right bank of the slope-area reach were surveyed, but the survey provided an accurate water-surface slope between cross sections 2 and 3 (James Stewart and Mastin and Kresch [2005] both used the same cross-section locations and identification; cross section 2 is upstream of the most downstream cross section, cross section 3). The field survey of the 2003 flood included HWMs on both sides of the river and detailed cross-sectional data; therefore, the water slope surveyed in 2006 was used in combination with the channel-geometry information for the 2003 flood to compute an $n$ value for the 2003 flood. Using this recalculated $n$ value, the discharge for the 1921 peak discharge was recalculated and re-evaluated. It was thought at the time of the 2006 survey that this data could be used to improve on the previous $n$-verification studies and provide a better verification of the 1921 peak discharge calculation.

\section{Purpose and Scope}

This report describes a re-evaluation of the 1921 peak discharge based on three lines of evidence: (1) the $n$-verification studies using the 1949 flood data, (2) the $n$ verification study using the 2003 and 2006 flood data, and (3) the location of the 1921 peak discharge data point on the stage-discharge rating - a relation defined by current-meter measurements made at the site.

The previous $n$-verification studies that used data from the 1949 flood are discussed in detail by Mastin and Kresch (2005). A re-examination of those studies is discussed in this report and results of that study are the main thread of evidence for the re-evaluation of the 1921 historic flood. The $n$-verification study using the 2003 and 2006 flood data is discussed first in this report because the results of the field survey of the flood HWMs on November 6-7, 2006, have not been documented in any previous report and the resulting well-defined water-surface slope was substituted into the 2003 flood channel roughness verification study to re-verify the roughness coefficient. This is followed by a discussion of the stage-discharge rating curve and how this curve is important as a third piece of evidence supporting the re-evaluation of the historical discharges at the gaging station on the Skagit River near Concrete, Washington.

\section{Field Survey of the 2003 Flood}

The HWMs and channel cross sections of the 2003 flood were surveyed in July-August 2004 at the same location used in the slope-area measurement made in 1923 (J.E. Stewart, U.S. Geological Survey, written commun., 1923). The site is a fairly straight reach of the Skagit River located downstream of the Dalles Gorge bedrock constriction, which is just downstream of the gaging station Skagit River near Concrete, Washington (station No. 121940000, fig. 1). A total station survey instrument was used to survey the cross sections and HWMs. During the cross-section survey, $2 \times 2$-inch wooden hubs were established near the site as survey control points based on Washington Department of Transportation survey monuments on the nearby highway. Elevation for the field survey was adjusted to the gage datum. 


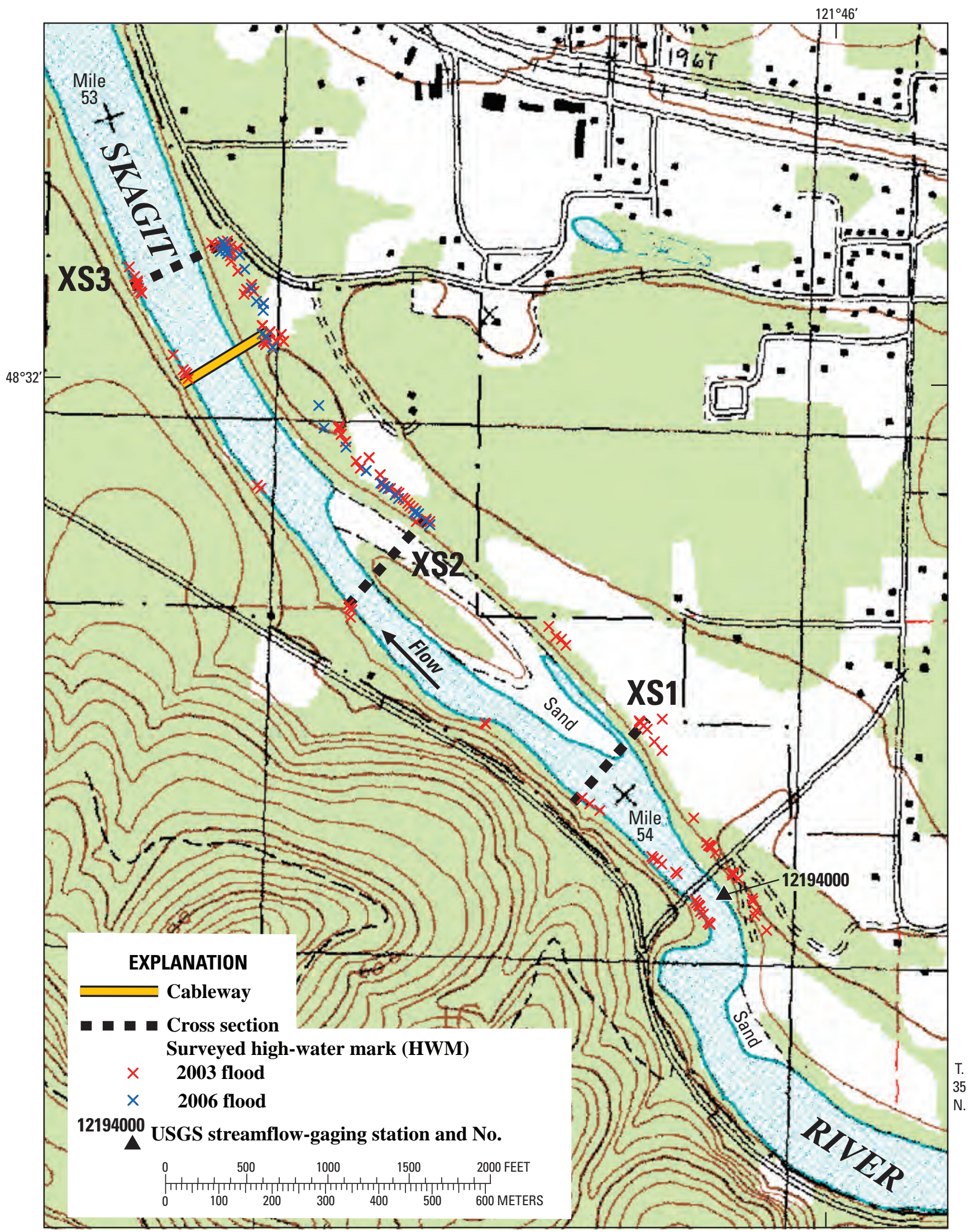

Figure 1. Topographic map of the slope-area measurement reach on the Skagit River near Concrete showing the three cross sections (XS1, XS2, and XS3), the streamflow-gaging station, and HWMs from the 2003 flood and the 2006 flood surveyed by the U.S. Geological Survey. 
HWMs were particularly difficult to find near cross section 1 (labeled XS1 in fig. 1) and marks that were found were rated poor. Most of the marks were scour lines, flooddeposited sand, mud lines or small debris piles. Cross section 1 is near a rapidly expanding section just downstream of the Dalles Gorge, where it is difficult to assess the amount of energy loss due to expansion. Slope-area calculations are best applied to reaches where bed friction losses dominate and are less accurate when applied to reaches with expansions. Because only limited, poor quality HWMs could be located and the difficulties in estimating the energy loss due to expansion, XS1 was not used and only XS2 and XS3 were used in a two-section slope-area calculation to estimate the $n$ value. Peak-flow discharge was determined from the stagedischarge rating for the gaging station supported by a currentmeter measurement of $138,000 \mathrm{ft}^{3} / \mathrm{s}$ on the day of the 2003 peak discharge. The water-surface elevation was well defined by HWMs at XS2, but there was about $2 \mathrm{ft}$ of scatter of the good and excellent HWMs at XS3. Because of the uncertainty of the water-surface elevation at XS3, only a range of plausible $n$ values ( 0.024 to 0.032 ) could be calculated for the 2003 flood.

Comparisons of channel cross sections and historical photographs (Mastin and Kresch, 2005) show that the channel has changed little in this particular reach of the Skagit River since 1923 except for the channel island (or channel bar at lower stages) crossed by XS2. This island/bar was likely barren and void of vegetation during the 1920s due to the series of large floods from 1897 to 1921 . A series of historical photographs beginning in 1937 (historical photographs on file at the U.S. Geological Survey, Washington Water Science Center) shows a barren island/bar that has gradually increased in the amount of established vegetation. This island/bar is now densely forested.

\section{Field Survey of the 2006 Flood}

On November 21, 2006, 2 weeks after the flood, a twoman crew from the USGS surveyed HWMs on the right bank from XS2 to XS3 using the same total station as used in the previous survey in 2004. On the day of the flood after the river had crested, Malcolm Leytham (Northwest Hydraulics Consultants) marked the high-water line with $1 \times 2$-inch hubs labeled with red poker chips (written comm., November 20, 2006). Five of these HWM hubs were found by USGS personnel, who also located 25 additional HWMs, each subjectively rated Excellent, Good, Fair to Poor (E, G, F, and $\mathrm{P})$ based on the condition, type, and accuracy of the mark. A straight stationing reference line was drawn on a map along the line of HWMs to provide stationing for each HWM in a longitudinal profile (fig. 2).

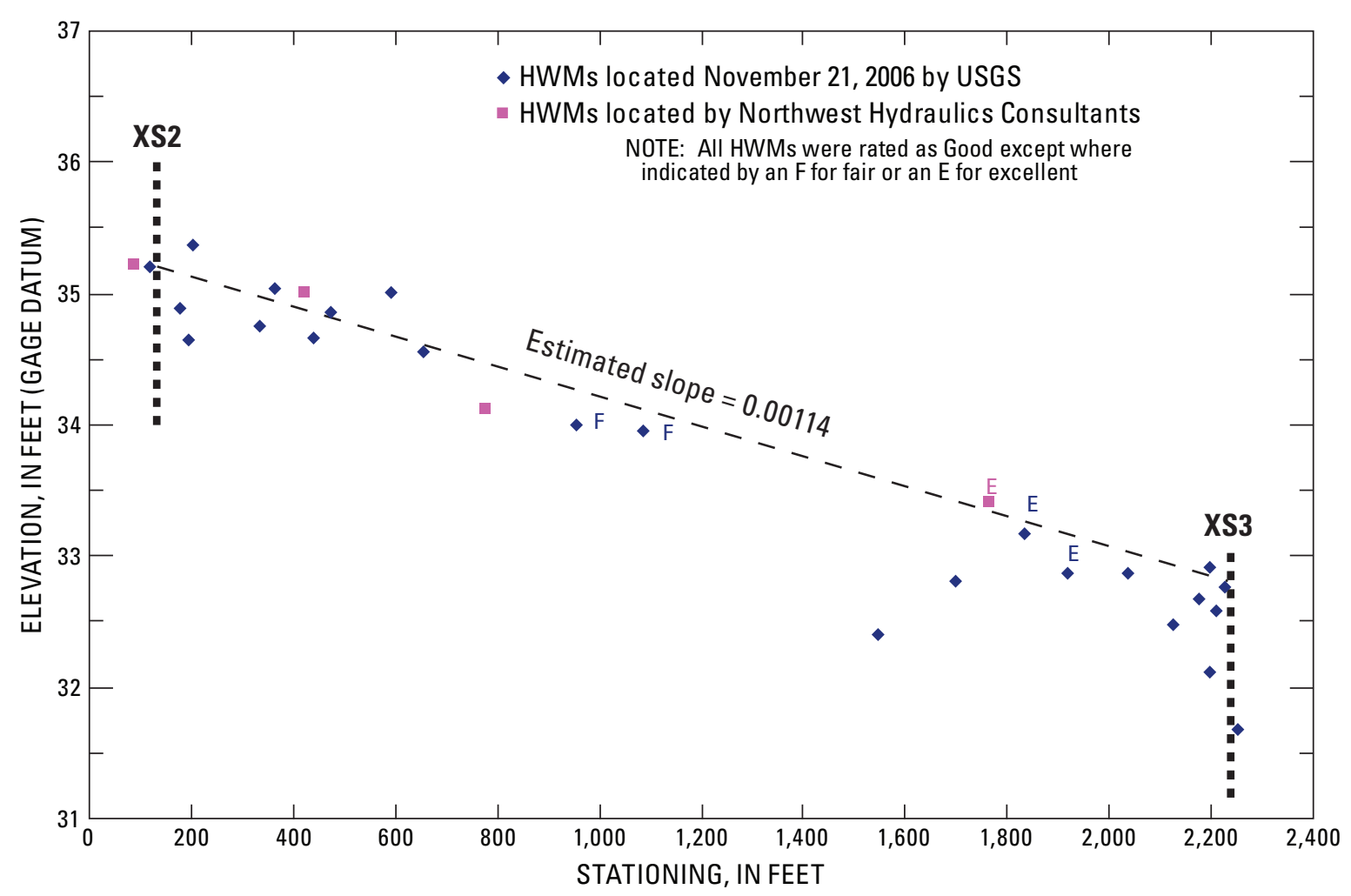

Figure 2. High-water marks (HWMs) from peak flow of November 6, 2006, that was surveyed November 21, 2006, by the U.S. Geological Survey on the right bank between cross sections 2 (XS2) and 3 (XS3) on the Skagit River about 3,000-5,000 feet downstream of the streamflow-gaging station, Skagit River near Concrete, Washington (station No. 12194000). 
Several $2 \times 2$-inch survey control hubs from the previous survey in 2004 were found and used to establish the survey control for the 2006 survey. The survey began near XS2 with two 2004 hubs that agreed within $0.025 \mathrm{ft}$ in the horizontal and $0.038 \mathrm{ft}$ in the vertical with the 2004 survey. The survey ended near XS3 on a 2004 hub (on a sand bank and found at an angle), checking the old coordinates within $0.082 \mathrm{ft}$ in the vertical and $3.003 \mathrm{ft}$ in the horizontal. The error in the horizontal is quite large, but this error may be partially due to movement of the hub in the sand bank. Positional checks were made between every total-station setup in the survey and they were all within $0.07 \mathrm{ft}$ in the horizontal and $0.02 \mathrm{ft}$ in the vertical. Ten setups were used along a baseline of about 2,100 $\mathrm{ft}$ to complete the survey. A 3-foot error in the horizontal length of the river $(2,108 \mathrm{ft})$ used to determine the water slope in this reach equals an error in the slope of \pm 0.15 percent.

\section{Calculated Water-Surface Slope for the 2006 Flood and the $n$ Value for the 2003 Flood}

Information from the 2003 and 2006 floods was combined to re-evaluate the $n$ value for the reach. The 2003 flood survey provided detailed channel geometry and HWMs on both sides of the river, but had a poorly defined watersurface slope due to the wide scatter of HWMs at XS3. The 2006 flood survey accurately measured the water-surface slope, but it did not include a survey of the cross sections or left-bank HWMs. If the slope estimated for the 2006 flood is substituted into the two-section equation for a slope-area measurement using the geometry surveyed for the 2003 flood, and utilizing the peak discharge for the 2003 flood, the $n$ value for this reach for the 2003 flood can be calculated.

\section{Water-Surface Slope for the 2006 Flood}

Figure 2 shows a profile of the HWMs from the peak of November 6, 2006, with the location of the cross sections and a straight line approximating the water surface at the peak. As a peak recedes, it may leave additional HWMs that are identified in the field. As a result, it is common to identify HWMs lower than nearby marks. A peak water surface generally is drawn with a bias to be nearest the highest water marks. Additional weight is given to water marks with the highest quality ratings. Despite having some scatter in the 2006 HWMs, the scatter of the HWMs is considerably less than the scatter of HWMs from the 2003 flood at XS3. Instead of providing a possible range in water-surface slopes as was done with the 2003 flood data, a single peak water-surface profile can be drawn for the 2006 flood that closely aligns with several HWMs at XS3 and several excellent HWMs just upstream of XS3. The water surface approximated in figure 2 has a slope of 0.00114 . This slope is in the range of values estimated from the survey of the HWMs from the 2003 flood, 0.00064 to 0.00124 , and it is very close to the slope of 0.00120 calculated by Stewart in 1923 for the 1921 flood (James Stewart, U.S. Geological Survey, written commun., November 1923).

Two recent medium-to-high discharge measurements plot close to the current rating without applying shifts. A discharge measurement made from a cableway on November 9, 2006, measured $53,000 \mathrm{ft}^{3} / \mathrm{s}$ and plotted +7.1 percent off the current rating without shifts. A discharge measurement of 138,000 $\mathrm{ft}^{3} / \mathrm{s}$ on October 21,2003 , plotted +1.5 percent off the same rating without shifts. These discharge measurements indicate that the hydraulics of the reach have changed little between the 2003 and 2006 floods. We, therefore, expect that the slope for the 2006 flood should be similar to the slope of the 2003 flood.

\section{n-Value for the 2003 Flood}

Initially, the surveyed cross section points for XS2 and XS3 for the 2003 flood were entered into the computer program Slope Area Computation, v97-01 (SAC, Fulford, 1994). The elevation of the water surface for XS2 was held to an elevation of $37.50 \mathrm{ft}$, a relatively accurate water-surface elevation determined from the survey of HWMs from the 2003 flood. The elevation of XS3 was set to $34.82 \mathrm{ft}$, the calculated elevation from applying a slope of 0.00114 to the reach length. As was done by Stewart in his 1923 calculation of the 1921 flood, no subdivision of the cross sections was made and $n$ values were held the same for both cross sections. By trial and error with the SAC program, the estimated $n$ value for the 2003 flood using the water-surface slope from the 2006 flood that resulted in a discharge of $166,000 \mathrm{ft}^{3} / \mathrm{s}$ (the peak discharge for the 2003 flood) was calculated to be 0.0306 . Calculated velocities were 11.1 and $12.1 \mathrm{ft} / \mathrm{s}$ and Froude numbers 0.43 and 0.46 for XS2 and XS3, respectively. This $n$ value is at the high end of the range of $n$ values calculated earlier by Mastin and Kresch (2005) — 0.024 for the flattest estimated watersurface slope and 0.032 for the steepest water-surface slope. James Stewart used the Chezy and Kutter equations (Corbett, 1962 , p. 81-83) along with an $n$ value of 0.033. Stewart, however, used the water-surface slope in his calculations rather than the energy slope that is used today, which results in slightly different peak-discharge values for the same $n$ values.

A close examination of the shape of XS2 indicated that a subdivision of the cross section should be done when performing one-dimensional hydraulic computations. The decision to subdivide follows guidelines outlined by Davidian (1984, p. 21) for "bench panhandle shapes" of cross sections. Davidian's guidelines state that cross sections should be subdivided when the ratio of the length of the panhandle to its depth is 5 or greater. In the case of XS2, the ratio is roughly 15 . A second $n$-verification computation was made with XS2 subdivided into two subareas, a main channel on the left 
half of the cross section and a high-water bench on the right half of the cross section containing the forested island/bar. The plot of XS2 from the 2004 survey indicates that three subareas may be warranted (left main channel, high-water bench, and right main channel). However, because the plot of XS2 from the 1923 survey shows only two subareas (on main channel and one panhandle area) only two subareas for the 2004-surveyed XS2 were used for consistency between the two calculations. No distinct panhandle shape is found in cross section XS3 so no subdivision of XS3 was used in the calculations. XS2 was subdivided at station 346 (fig. 3) for the cross section data surveyed in 2004. Using a weighted-wetted perimeter technique (Arcement and Schneider, 1989) for the panhandle portion of XS2, the $n$ value of the right subarea was calculated to be 0.066 based on an estimated $n$ value of 0.120 for the forested island/bar portion (station 346 to 486, wetted perimeter $=140 \mathrm{ft}$ ) and 0.033 for the remainder of the subarea (wetted perimeter $=231 \mathrm{ft})$. Therefore; $0.066=((0.120 * 140)$ $+(0.033 * 231)) / 371$. The $n$ value for the forested island (0.120) was estimated from photographs of verified $n$ values for floodplain reaches (Arcement and Schneider, 1989). The $n$ value of the remainder of the right subarea of XS2 was set to Stewart's original $n$ value for the reach, 0.033 .
Several trial-and-error runs of the SAC program were performed to determine the $n$ value for the left subarea of XS2 and all of XS3, which are considered to be the main channel in this reach of the Skagit River. Running the SAC program to produce a discharge as close to the 2003 flood peak as possible $\left(166,000 \mathrm{ft}^{3} / \mathrm{s}\right)$, an $n$ value of 0.033 was calculated for the main channel areas (a discharge of $168,000 \mathrm{ft}^{3} / \mathrm{s}$ resulted in an $n$ value of 0.033 , and a discharge of $163,000 \mathrm{ft}^{3} / \mathrm{s}$ resulted in an $n$ value of 0.034 ).

\section{Recalculating the 1921 Peak Discharge}

The final $n$ value of 0.033 for the main channel areas that was calculated for the 2003 flood and the slope for the 2006 flood was used to recalculate the 1921 peak discharge using cross-section geometry, reach length, and fall from Stewart's 1923 survey (James Stewart, U.S. Geological survey, written commun., November 1923). For this recalculation, XS2 from the 1923 survey was subdivided into two areas at station 256 (see fig. 3) based on the guidelines discussed previously.

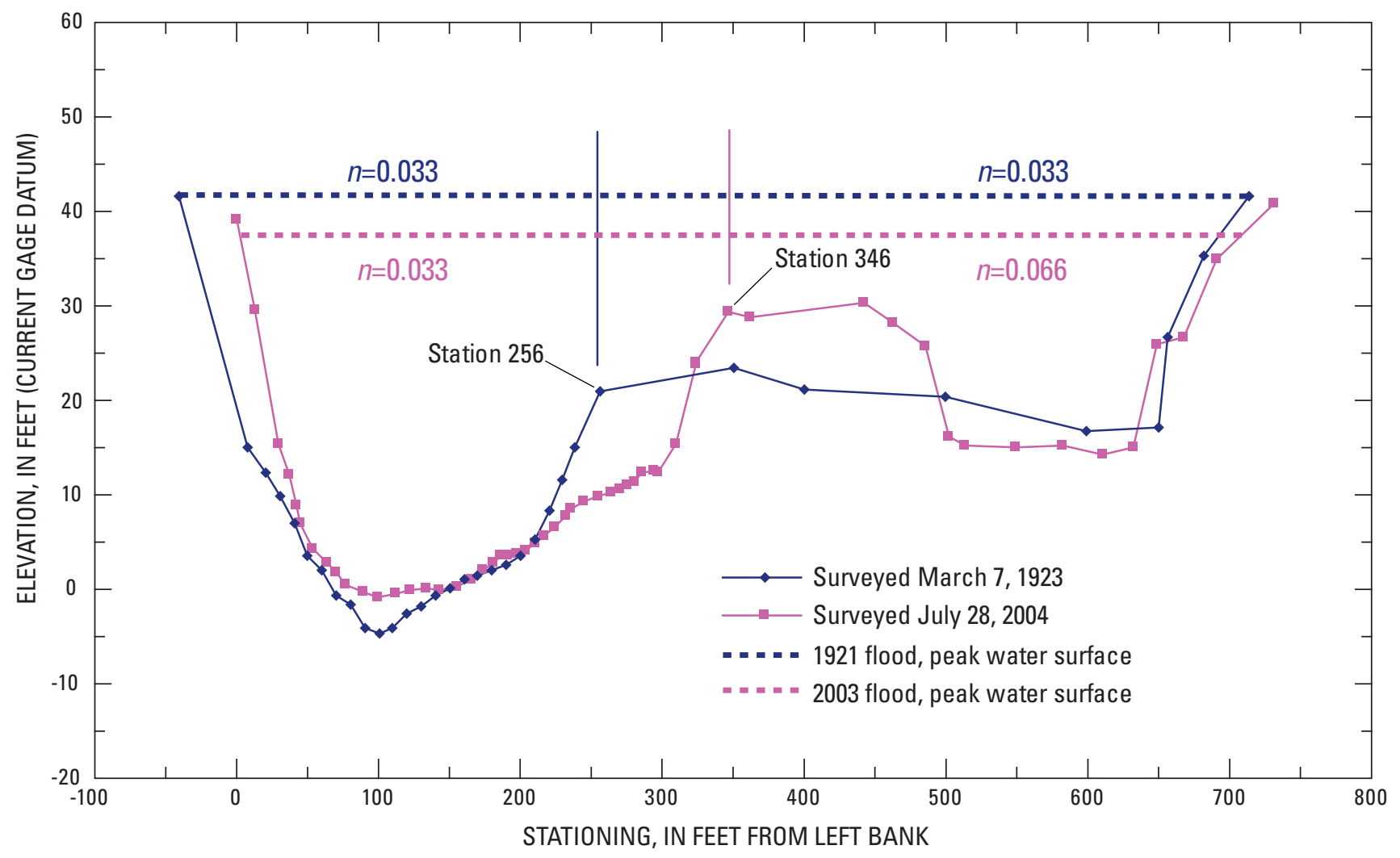

Figure 3. Cross section XS2 as surveyed in 1923 and 2004, $n$ values for the particular subareas ( $n$ ), peak water surface for the 1921 and 2003 floods, and the points at which the cross sections were subdivided into two subareas. [Note: Stationing for the 1923 surveyed cross section was adjusted to fit the stationing surveyed in 2004.] 
Even though XS2 was subdivided, an $n$ value of 0.033 was used for both subareas because the island/bar was assumed to be bare of vegetation at the time of the 1921 peak with similar roughness elements as the main channel. The resulting recalculated peak discharge is $219,000 \mathrm{ft}^{3} / \mathrm{s}$.

A re-examination of the $n$-verification done by Flynn and Benson (U.S. Geological Survey, written commun., August 1952) using the 1949 flood data also computed an $n$ value that could be used to recalculate the 1921 peak discharge. In both recalculations, Stewart's surveyed data for the reach between XS2 and XS3 were used with the different $n$ values to calculate different peak discharges for the 1921 flood.

Recalculation of the 1921 peak using an $n$ value calculated from 2003 and 2006 data assumes that the channel roughness conditions and hydraulics of the reach have not changed since 1921. However, this assumption may not be valid because the island/bar that probably was bare of vegetation in 1921 has built up slightly from deposition (fig. 3) and is now densely forested (Stewart's survey notes for his indirect measurements in 1923 do not mention anything about the vegetative character of the island). This alteration of the island/bar probably has complicated the flow hydraulics, which makes the recalculation of the 1921 flood using 2003 and 2006 flood data less reliable.

A more reliable recalculation of the 1921 flood peak may be obtained using the analysis of the 1949 flood because the conditions in the reach in 1949 may have been more similar to the conditions in 1921. In fact, a 1932 and a 1948 photograph show the island/bar mostly bare of vegetation (fig. 4). The 1948 photograph indicates that the influence of vegetation on the island/bar was minimal prior to the November 1949 flood that was used for the $n$-verification study by Flynn and Benson (U.S. Geological Survey, written commun., August 1952).

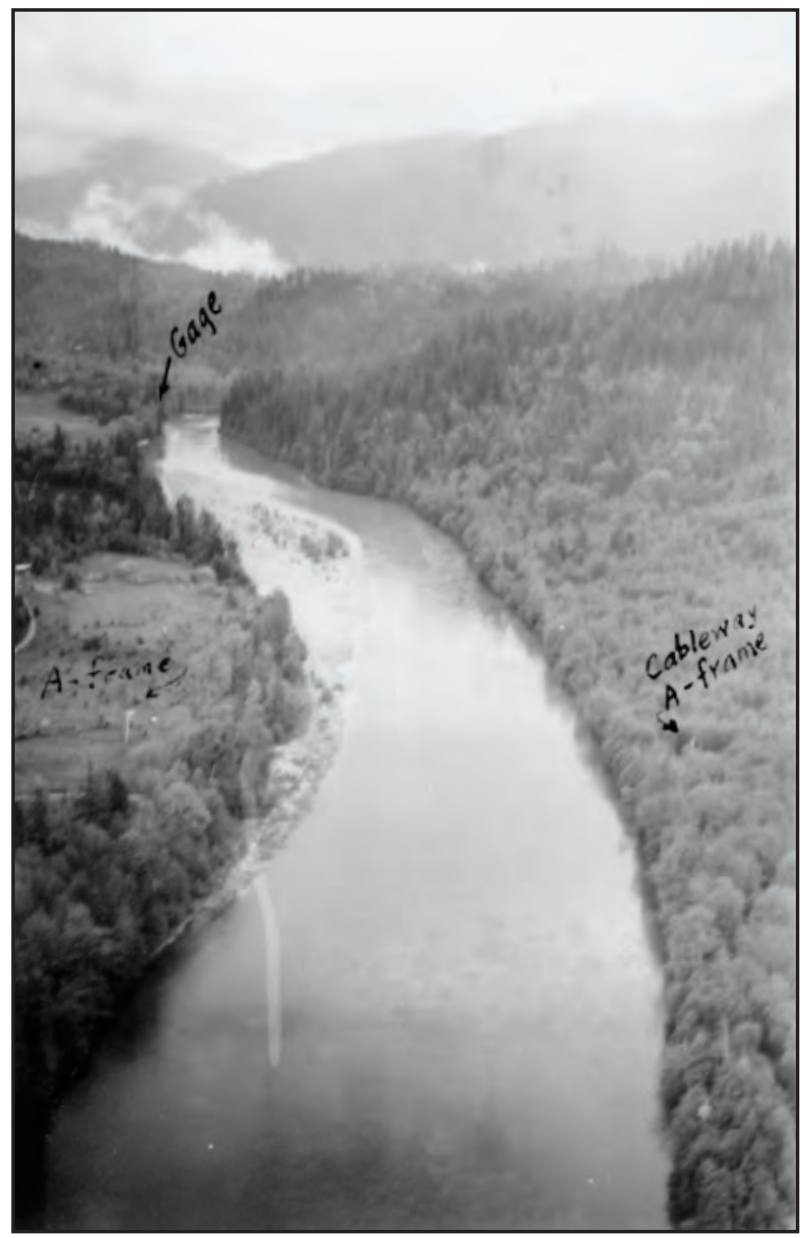

B. Skagit River near Concrete, Washington. Looking upstream. Photograph taken from helicopter by F. Veatch., U.S. Geological Survey, May 8, 1948. downstream from top of gage house. Photograph taken by J. Bonner, U.S. Geological Survey, June or July 1932.

Figure 4. Historical photographs showing only small, sparse brush on the island/bar near cross section 2, Skagit River, Washington. Historical photographs on file at the U.S. Geological Survey, Washington Water Science Center. 


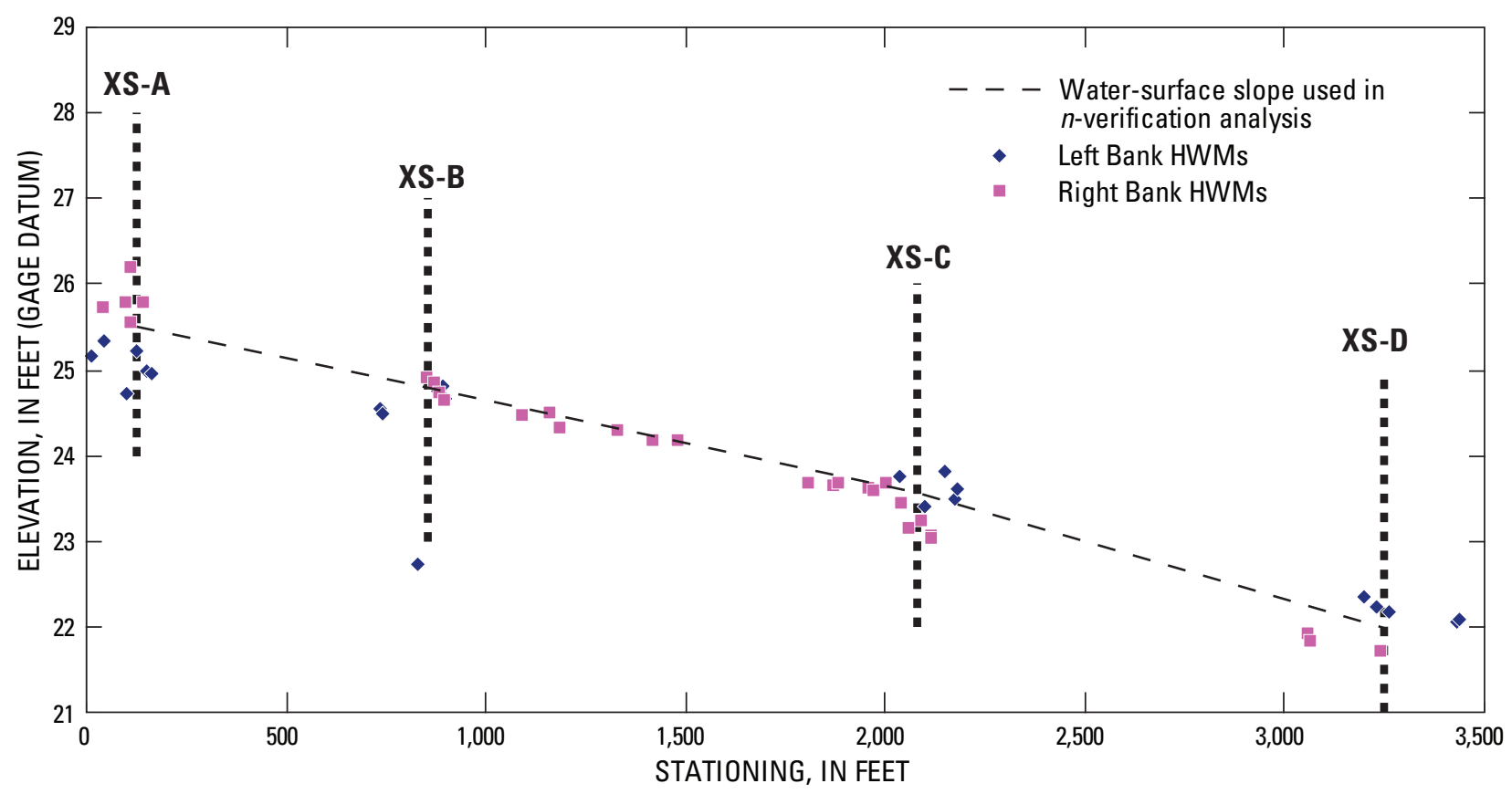

Figure 5. High-water marks (HWMs), cross sections (XS), and water-surface profile from the peak flow of November 27, 1949 on the Skagit River about 3,000-5,000 feet downstream of the streamflow-gaging station, Skagit River near Concrete, Washington (station No. 12194000).

Flynn and Benson (F.J. Flynn and M.A. Benson, U.S. Geological Survey, written commun., August 1952) computed an $n$ value of 0.0305 for the 1949 flood data, and using that $n$ value, Flynn and Benson recalculated the 1921 peak discharge to be $225,000 \mathrm{ft}^{3} / \mathrm{s}$. They surveyed four cross sections labeled A through $\mathrm{D}$ in downstream order beginning with $\mathrm{A}$ at the upstream end about $300 \mathrm{ft}$ downstream of Stewart's cross section 1. Cross sections B and C fell on either side of Stewart's cross section 2 and cross section D was about $700 \mathrm{ft}$ upstream of Stewart's cross section 3. Reach A-B was not used because of the large expansion in the reach. The surveyed HWMs provided a reasonably accurate water-surface profile for the 1949 flood (fig. 5); however, the analysis did not subdivide any of the cross sections.

Looking at the shape of cross sections B and C (fig. 6), and using the guidelines that are now available for subdividing (Davidian, 1984), the cross sections clearly needed to be subdivided. Based on these guidelines, cross sections B and C were subdivided and the 1949 analysis was recomputed in order to come up with a revised $n$ value for the 1949 study. Through trial and error with the SAC program using different $n$ values, an $n$ value of 0.0315 provided a calculated discharge of $154,000 \mathrm{ft}^{3} / \mathrm{s}$ for the reach from $\mathrm{B}$ to $\mathrm{D}$, which is very near the 1949 flood discharge of $153,000 \mathrm{ft}^{3} / \mathrm{s}$. Using this $n$ value in the recalculation of the 1921 flood using Stewart's data with a subdivided cross section 2 as described above, resulted in a discharge of $228,000 \mathrm{ft}^{3} / \mathrm{s}$.

In summary, two recalculations of the 1921 peak discharge based on two $n$-verification analyses, one using
1949 peak-flow data and one using the 2003 and 2006 peakflow data, both resulted in discharges less than Stewart's original calculated discharge. The recalculated value of $228,000 \mathrm{ft}^{3} / \mathrm{s}$ for the 1921 peak discharge that used 1949 peakflow data and subdividing techniques is 5.0 percent less than Stewart's original value of $240,000 \mathrm{ft}^{3} / \mathrm{s}$ and the recalculated value of $219,000 \mathrm{ft}^{3} / \mathrm{s}$ that used 2003 and 2006 peak-flow data and subdividing techniques is 8.8 percent less than Stewart's original value. The slope-area recalculation of the 1921 peak flow using the $n$ value from 1949 peak $n$-verification analysis and subdivision is considered a fair measurement within 15 percent of the actual value (Benson and Dalrymple, 1967). Note that Stewart's calculation falls well within the error bounds of this recalculated peak discharge. The roughness due to vegetation on the island/bar in 1949 is likely to have been minimal as it was in 1921, but much different than the 2003 or 2006 peak flows. Due to the complication of the hydraulics of flow through and around the forested island/bar, more confidence can be given to the recalculation of the 1921 peak based on the 1949 peak when the reach conditions were more similar to 1921 than in 2003 or 2006 . The recalculation of the 1921 peak discharge using the 2003 and 2006 peak discharge information is only 2.7 percent less than the recalculation based on the 1949 peak discharge information. Despite some doubt in the accuracy due to the complications of accounting for the hydraulics around and through the forested island/ bar, the recalculation of the 1921 peak using 2003 and 2006 information supports the assertion that Stewart's original value for the 1921 peak is too high. 

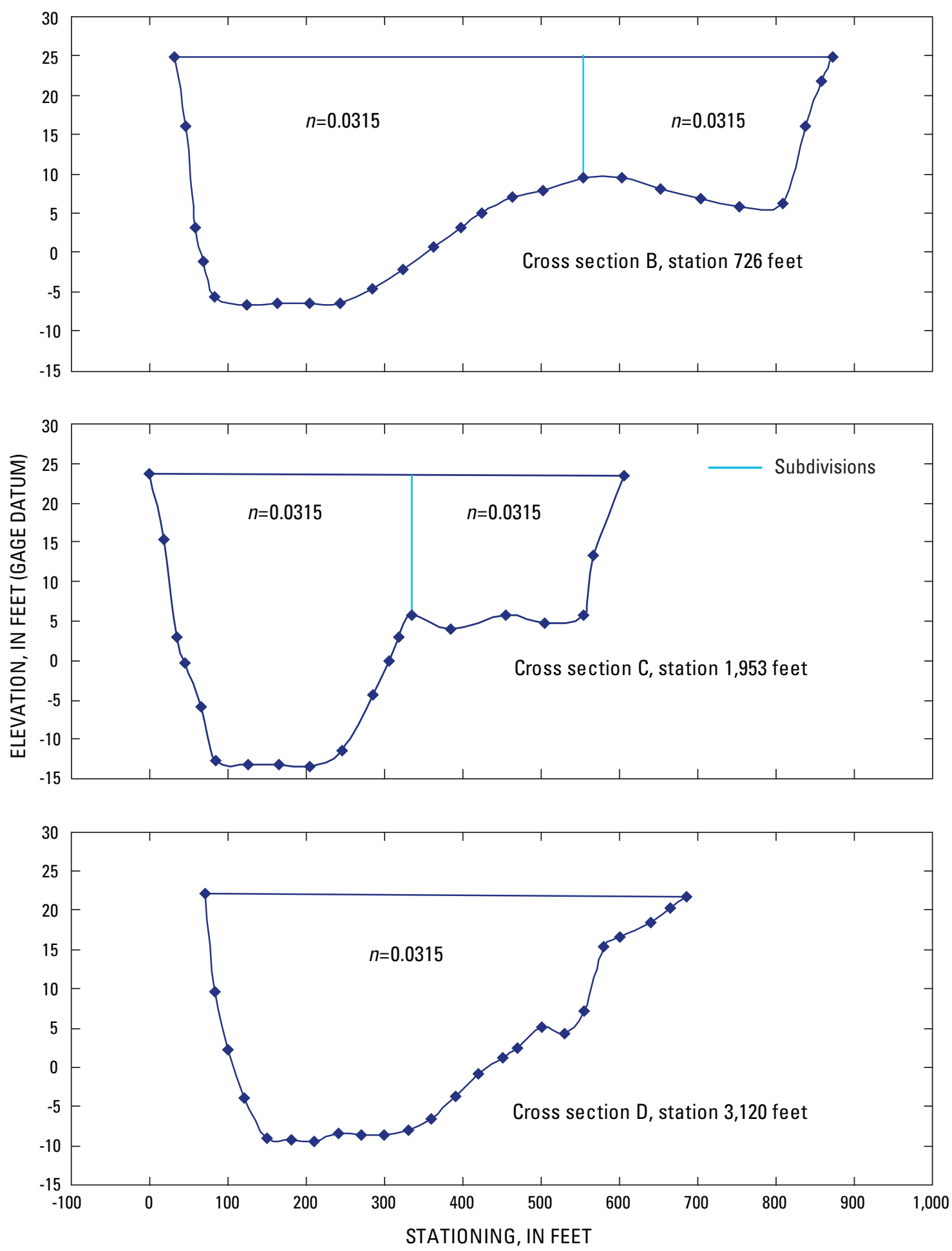

Figure 6. Cross sections $\mathrm{B}, \mathrm{C}$, and $\mathrm{D}$ and the $n$ values $(n)$ used in the $n$-verification study based on the 1949 peak discharge at Skagit River near Concrete, Washington. 


\section{Historic Peak Discharges Based on the Stage-Discharge Rating}

Another indicator that the published historical discharges may be too high is the location of the peak-discharge data points that plot to the right of the current stage-discharge rating curve at the site. This rating was extended based on current high-flow current-meter measurements; the highest is measurement number 475 that was made on October 21, 2003, at a discharge of $138,000 \mathrm{ft}^{3} / \mathrm{s}$ (fig. 7). The primary channel feature that controls the stage-discharge rating at this site is a bedrock gorge that is relatively immune to typical scour and fill activities common to many rating controls. The lack of scatter in the long history of current-meter measurements on the plot of the stage-discharge rating supports this conclusion of a stable rating that has not changed substantially over the last 80 years. The channel geometry does not substantially change at the highest stages, which indicates that a straightline extension of the rating beyond the highest current-meter measurement is a reasonable method to estimate high flows. Water year 1925 discharge measurements are highlighted in figure 7 because they represent the stage-discharge relation near the time of the historic floods.

In order to revise the historical peak discharges based on a revised peak discharge for the 1921 peak discharge $\left(228,000 \mathrm{ft}^{3} / \mathrm{s}\right)$, a new rating was drawn. Using the water year 1925 discharge measurements, the highest current-meter measurements, and constraining the rating curve to pass directly through the recalculated 1921 peak discharge data point, a rating curve was redrawn and extended with a straight line to a gage height of 69.3 feet, the estimated gage height for the 1815 peak discharge (fig. 7).

\section{SKAGIT RIVER NEAR CONCRETE, WASHINGTON 12194000}

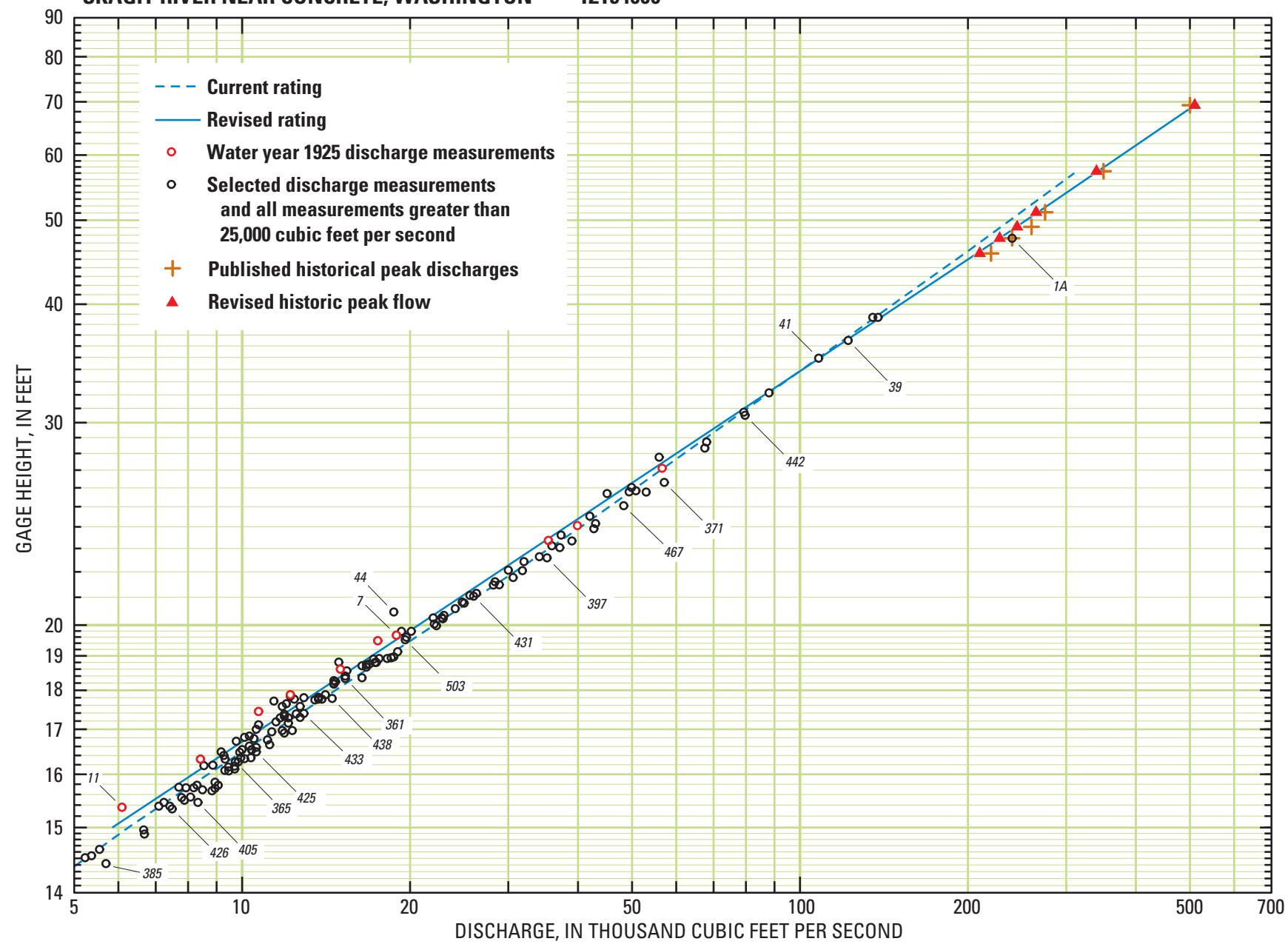

Figure 7. Stage-discharge rating based on revised 1921 peak discharge recalculation extended to a gage height of 69.3 feet and the current stage-discharge rating for Skagit River near Concrete, Washington, showing selected discharge measurements, published historical peak discharges, and the proposed revised historic peak flows. 


\section{Re-evaluating the Historic Peak Discharges}

A SAC run using the 2003 and 2006 flood data to calculate the discharge for various roughness coefficients calculated a velocity of $12.1 \mathrm{ft} / \mathrm{s}$ for XS3, but the velocities calculated in the subareas for XS2 were $14.3 \mathrm{ft} / \mathrm{s}$ for the left main channel and $4.9 \mathrm{ft} / \mathrm{s}$ in the right high-water bench. With the obstruction of the forested island/bar and such a large difference in the velocities in the two subareas, flows during peaks are not expected to be parallel to the banks of the reach because they would be going around the forested island/bar. Non-parallel flows would introduce some head losses that are not accounted for in the calculation of the energy equation, and for these reasons introduce some error in the calculation that are impossible to quantify. A detailed two-dimensional flow model could possibly account for these losses, but one is not currently available for this analysis. The $n$-verification study done for the 1949 flood did not have this problem because the island/bar was practically barren and flows were more likely to be parallel to the bank. Due to these hydraulic complications in the 2003 and 2006 peak flow $n$-verification calculations and the fact that the study reach in 1949 was more similar to the reach in 1921 than it was in 2003 or 2006, there is more confidence in the $n$ verification and subsequent 1921 peak-flow recalculation based on the 1949 peak flow than the calculations using only the 2003 and 2006 peak-flow data.

Novak (1985) discusses the USGS criteria for revisions of peak flows as follows:

"Extremes and peaks greater than base discharge should be revised if the difference in discharge between old and new data is more than about 10 percent. Revisions may be made for errors less than 10 percent if they are needed to maintain the correct relationship between the annual maximum discharge or to keep annual maximums in the proper order of magnitude."

The revised discharge values reported by Flynn and Benson in their unpublished report from1952 is less than 10 percent different than the published value, and because the magnitudes of the three other historic peaks that occurred in 1897, 1909, and 1917 are dependent on the magnitude of the 1921 peak discharge, Bodhaine, the USGS area engineer at the time, felt that a revision would not be needed (G.L. Bodhaine, U.S. Geological Survey, written commun., May 1954). Since that time, two new independent $n$-verification studies as described in this report came up with a similar conclusion that the currently published peak flows are too high. Together with the straight-line extension of the stage-discharge relation, there are now three independent estimations that all are lower than the published values.

The accuracy of the peak discharge of the four historic floods at this site is essential to the current flood-reduction study by the U.S. Army Corps of Engineers and the Skagit County Flood Insurance Study Update by FEMA. In order to provide the best data available for the current flood studies, the USGS revised historic floods at Skagit River near Concrete despite the fact that their estimates are all less than 10 percent from the currently published discharges (table 1). The 1921 peak discharge is determined from the recalculation using Stewart's data, subdivision of cross section 2, and the $n$ value calculated from the $n$ verification using 1949 peak-flow data as described in this report. The other historical peak discharges are revised based on the rating extension described in this report and rounded to the nearest $5,000 \mathrm{ft}^{3} / \mathrm{s}$ (table 1).

Table 1. Revised peak discharges for Skagit River near Concrete, Washington.

[ $\mathrm{ft}^{3} / \mathrm{s}$, cubic foot per second]

\begin{tabular}{ccccc}
\hline Year & $\begin{array}{c}\text { Currently } \\
\text { published peak } \\
\text { discharges } \\
\left.\text { (ft } \mathbf{f t}^{3} / \mathbf{s}\right)\end{array}$ & $\begin{array}{c}\text { Gage height } \\
\text { (ft) } \\
\text { (current } \\
\text { datum) }\end{array}$ & $\begin{array}{c}\text { Revised peak } \\
\text { discharges } \\
\text { (ft } \mathbf{t}^{\mathbf{3}} \mathbf{s} \text { ) }\end{array}$ & $\begin{array}{c}\text { Percent } \\
\text { difference } \\
\text { in revised } \\
\text { discharge }\end{array}$ \\
\hline 1815 & 500,000 & 69.3 & 510,000 & 2.0 \\
1856 & 350,000 & 57.3 & 340,000 & -2.9 \\
1897 & 275,000 & 51.1 & 265,000 & -3.6 \\
1909 & 260,000 & 49.1 & 245,000 & -5.8 \\
1917 & 220,000 & 45.7 & 210,000 & -4.5 \\
1921 & 240,000 & 47.6 & 228,000 & -5.0 \\
\hline
\end{tabular}




\section{Summary}

In 1952 and 1954, the U.S. Geological Survey investigated a revision of the historic floods at Skagit River near Concrete based on a revision of the 1921 peak-flow discharge that used a revised channel roughness coefficient calculated from the 1949 peak discharge. At the time, the recomputations were not used to change the published values because the proposed revisions were all less than 10 percent. Recently, a new channel roughness coefficient verification was made using the water-surface slope of the 2006 flood at Skagit River near Concrete along with channel geometry and high-water marks from the 2003 flood. The recalculation of the 1921 peak discharge using this new roughness coefficient and a subdivision of the cross sections also indicated that the original computation of the 1921 peak discharge by James Stewart in 1923 was too high although well within the margin of error. However, the island/bar in the slope-area reach thought to have been barren during the 1921 and 1949 peak discharges has re-vegetated into a dense forest, and it is likely altering the flow patterns during high flows. The slope-area computation does not solve for these complex flow patterns in two dimensions, and therefore, the recalculation based on a verified channel roughness coefficient using the 1949 flood data and channel characteristics and subdividing techniques is thought to more accurately reflect 1921 conditions. The recalculated peak discharge for the 1921 flood using the channel roughness coefficient verified using 1949 flood data is 5.0 percent less than the published value computed in 1923. The current stage-discharge relations at the station also indicate that the lower peak discharge value is more reasonable than the published value. With these several lines of evidence that all indicate that the published value of the 1921 peak is too high, the USGS will revise the historical peak discharges. The 1921 peak discharge will be revised to $228,000 \mathrm{ft}^{3} / \mathrm{s}$ or 5.0 percent less than the published value, and correspondingly, the other historical peak discharges will be revised from straight-line extension of a revised stage-discharge rating that passes through the revised 1921 peak-discharge data point.

\section{References Cited}

Arcement, G.J., Jr., and Schneider, V.R., 1989, Guide for selecting Manning's roughness coefficients for natural channels and flood plains: U.S. Geological Survey WaterSupply Paper 2339, 38 p.

Benson, M.A., and Dalyrymple, T., 1967, General field and office procedures for indirect discharge measurements: U.S. Geological Survey Techniques of Water-Resources Investigations, Book 3, Chap. A1, 30 p.

Corbett, D.M., 1962, Stream-gaging procedure-A manual describing methods and practices of the Geological Survey: U.S. Geological Survey Water-Supply Paper 888, 245 p.

Davidian, J., 1984, Computation of water-surface profiles in open channels: U.S. Geological Survey Techniques of Water-Resources Investigations, Book 3, Chap. A15, 48 p.

Fulford, J.M., 1994, User's guide to SAC, a computer program for computing discharge by the slope-area method: U.S. Geological Survey Open-File Report 94-360, 31 p.

Mastin, M.C., and Kresch, D.L., 2005, Verification of 1921 peak discharge at Skagit River near Concrete, Washington, using 2003 peak-discharge data: U.S. Geological Survey Scientific Investigations Report 2005-5029, v. 2.0, 18 p.

Novak, C.E., 1985, WRD data reports preparation guide: U.S. Geological Survey Water Resources Division, 199 p. 
Manuscript approved for publication, August 8, 2007

Prepared by the USGS Publishing Network,

Bill Gibbs

Bob Crist

Bobbie Jo Richey

Linda Rogers

For more information concerning the research in this report, contact the Washington Water Science Center Director,

U.S. Geological Survey, 934 Broadway - Suite 300

Tacoma, Washington 98402

http://wa.water.usgs.gov 
